\title{
IN VITRO CONCENTRATION OPTIMIZATION OF ETHANOL EXTRACT FROM MAKASAR FRUIT SEEDS (Brucea javanica L. Merr) AS AN ANTI-INFLAMMATORY AGENT
}

\author{
Diva Almira*, Windah Anugrah Subaidah, Agus Dwi Ananto, Rizqa Fersiyana Deccati, and \\ Handa Muliasari \\ Pharmacy Study Program, Faculty of Medicine, University of Mataram, Mataram, Indonesia \\ *Email: divaalmira48@gmail.com
}

Accepted: October, 27 2021. Approved: November, 10 2021. Published: November, 152021

\begin{abstract}
Anti-inflammatory medications are necessary to treat excessive inflammation reactions due to injury, infection, or irritation. The emergence of several adverse effects of synthetic anti-inflammatory drugs has prompted the continued use of anti-inflammatory agents derived from natural products with low side effects and a high therapeutic effect. While it is well established that the seeds of the Makassar fruit (Brucea javanica (L.) Merr.) have anti-inflammatory activity, the optimal concentration of Makasar fruit seed extract for antiinflammatory activity is unknown. This study aims to determine the optimal Makassar fruit seed extract concentration in vitro anti-inflammatory. The seeds of the Makasar fruit were extracted using the sonication method ( 3 x 35 minutes) in 96\% ethanol and then concentrated using a rotary evaporator. The secondary metabolites of Makasar fruit seed extract were then identified in the test tubes, and the anti-inflammatory activity was determined using the protein denaturation inhibition method. The results indicated that the extract produced had a yield of $10.03 \%$. The Makassar fruit seed extract contains secondary metabolites of phenolics, flavonoids, and terpenoids. Makasar fruit seed extract exhibited the optimum anti-inflammatory activity at a concentration of $1 \%$, with a $55.47 \%$ inhibition of protein denaturation.
\end{abstract}

Keywords: Anti-inflammatory, Makassar fruit (Brucea javanica (L.) Merr.), Protein denaturation.

\section{INTRODUCTION}

Inflammation is the body tissue's natural response to injury, infection, or irritation caused by physical trauma, toxic chemicals, or microbes [1]. However, if the inflammatory response is excessive, anti-inflammatory drugs are required to maintain a safe level of inflammation. Most of the antiinflammatory drugs on the market are synthetic chemicals. These chemicals cause adverse skin reactions such as rashes and itching on all skin types. Therefore, we need anti-inflammatory medicines derived from natural ingredients with low side effects and high therapeutic effects [2].

One of the natural medicinal ingredients used as an anti-inflammatory is the Makassar plant. Makassar plant (Brucea javanica (L.) Merr.) is a perennial erect shrub that grows wild in Indonesia. The fruit of this plant is frequently used in traditional medicine to prevent dysentery, diarrhea, and malaria and has been shown to have a hypoglycemic effect in rats treated with alloxan $[3,4]$. According to previous research, the ethanol-water extract of the Makasar plant has been shown to reduce swelling in rats induced by croton oil, indicating that this plant possesses anti-inflammatory activity [5]. The ethyl acetate fraction of Makasar seeds in vitro and in vivo can inhibit the production of inflammatory mediators such as NO, PGE2, TNF- $\alpha$, IL-1 $\beta$, and IL-6 and promote the production of anti-inflammatory cytokines, specifically IL-10 [6]. The makasar fruit seed oil has anti-inflammatory properties, as evidenced by the lengthening of the colon and inhibition of NF-kB signal transduction in rats induced with Dextran Sulfate Sodium (DSS) [7]. Amini et al. (2020) reported that a cream containing a $96 \%$ ethanol extract of Makasar fruit seeds might protect against skin inflammation in mice [8].

Based on these numerous references, Makassar fruit seeds can be developed as an antiinflammatory agent. However, the optimal concentration of Makasar fruit seed extract as an anti-inflammatory agent has not been reported. Thus, an in vitro study was conducted to determine the optimal concentration of Makasar fruit seed extract (Brucea javanica (L.) Merr.) as an antiinflammatory agent. The anti-inflammatory test method used in this study was the protein denaturation inhibition method with Bovine Serum Albumin (BSA). One of the causes of inflammation is protein denaturation. Thus, it is necessary to identify an active compound with a specific concentration that can act as an inhibitor of protein denaturation and thus aid in the development of anti-inflammatory drugs.

\section{RESEARCH METHOD Materials}

Makasar fruit (Brucea javanica (L.) Merr.), ethanol 96\%, $\mathrm{FeCl}_{3}$, concentrated $\mathrm{HCl}, \mathrm{Mg}$ powder, chloroform, acetic anhydride, concentrated $\mathrm{H}_{2} \mathrm{SO}_{4}$, bovine serum albumin (BSA), tris base, glacial acetic acid, $\mathrm{NaCl}$, diclofenac sodium, aquadest. 


\section{Sample Collection and Processing}

Samples of dark purple-black-colored Makasar fruit were collected from the Sesaot area, West Lombok Regency, West Nusa Tenggara. Sample identification was carried out at the Advanced Biology Laboratory, Faculty of Mathematics and Natural Sciences, the University of Mataram with letter number 08/UN18.7/LBL/2021. The sample is then separated from the peel and dried. Makasar fruit seeds are then ground into Simplicia powder.

\section{Preparation of Extract}

A total of $100 \mathrm{~g}$ of Makasar fruit seed powder was extracted using the sonication method $(3 \times 35$ minutes; room T) with ethanol $96 \%$. The ratio of Makasar fruit seed powder: ethanol 96\% was 2:5. Subsequently, filtration was used to obtain the extract, then concentrated using a rotary evaporator set to $40^{\circ} \mathrm{C}$ [9].

\section{Phytochemical Screening}

Phytochemical screening was carried out qualitatively in a test tube. Phenolic test by dripping $\mathrm{FeCl}_{3}$. Flavonoid test by adding concentrated $\mathrm{HCl}$ and $\mathrm{Mg}$ powder. Terpenoid test by adding chloroform, acetic anhydride, and concentrated $\mathrm{H}_{2} \mathrm{SO}_{4}$.

\section{In vitro Anti-inflammatory Activity Test}

The in vitro anti-inflammatory activity test refers to Farida et al (2018) study with modifications [10].

\section{Preparation of Reagent}

\section{a. Preparation of Tris Buffer Saline (TBS)}

$4.35 \mathrm{~g}$ of $\mathrm{NaCl}$ was dissolved in $200 \mathrm{~mL}$ of aquadest. Then, $605 \mathrm{mg}$ of Tris Base was added to the $\mathrm{NaCl}$ solution, and then water was added until the volume reached $400 \mathrm{~mL}$. The $\mathrm{pH}$ of the solution was adjusted by adding glacial acetic acid to $\mathrm{pH}$ 6.26.5 (pathological pH). Subsequently, aquadest was added until the volume reached $500 \mathrm{~mL}$.

b. Preparation of $0.2 \%$ Bovine Serum Albumin (BSA) in TBS

$0.2 \mathrm{~g}$ of Bovine Serum Albumin (BSA) was dissolved in a TBS solution to a volume of $100 \mathrm{~mL}$.

\section{Preparation of Makasar Fruit Seed Extract Solution}

$2.5 \mathrm{~g}$ of extract was dissolved in a $50 \mathrm{~mL}$ volumetric flask, and aquadest was added up to the limit mark to obtain a mother liquor with a concentration of $5 \%$. Then, the dilution was carried out to provide various concentrations.

\section{Preparation of Diclofenac Sodium Solution as Positive Control \\ $0.5 \mathrm{~g}$ of diclofenac sodium was dissolved in} a $50 \mathrm{~mL}$ volumetric flask, and aquadest was added to the mark. The mother liquor was obtained with a concentration of $1 \%$. Furthermore, dilution was carried out to provide various concentrations.

\section{Preparation of Test Solution}

As much as $500 \mu \mathrm{L}$ of the test solution (extract, sodium diclofenac as a positive control, and aquadest as a negative control) was pipetted. Then, BSA solution $0.2 \%$ was added to a volume of $5 \mathrm{~mL}$. This process was repeated for each concentration variation.

\section{In vitro Anti-Inflammatory Activity Test}

Each solution added to BSA was incubated for 30 minutes at a temperature of $\pm 25^{\circ} \mathrm{C}$. It heated for 5 minutes at a temperature of $\pm 72^{\circ} \mathrm{C}$ with a water bath. Then, the mixture was cooled off for 25 minutes at room temperature, and the absorbance was measured using a UV-Visible spectrophotometer at a wavelength of $660 \mathrm{~nm}$. The calculation of the percentage of protein denaturation inhibition follows the formula below:

$$
\% \text { inhibition }=\frac{\text { control abs }- \text { test solution abs }}{\text { control abs }} \times 100 \%
$$

Note:

Control abs $=$ negative control absorbance

Anti-inflammatory activity was indicated by the value of $\%$ inhibition $>20 \%$.

\section{RESULTS AND DISCUSSION \\ Makasar fruit seed ethanol extract}

The extraction process of Makasar fruit seeds used ethanol $96 \%$ because ethanol is a polarsemi-polar solvent capable of extracting secondary metabolites, specifically phenolic, flavonoid, and terpenoid compounds that match the target combinations in this study [11]. The sonication extraction method was chosen because this method uses ultrasonic waves, which will propagate in water and break down plant cell walls, allowing the desired compound to escape and dissolve in the solvent more easily [12]. Reyes et al. (2013) reported that extraction by sonication method yielded more phenolic compounds than maceration [13]. Makassar fruit seed extract was yielded by $10.03 \%$ in this study. The yield of the section obtained using the maceration method was $7.4 \%$ greater than in the previous study [8].

\section{Phytochemical Screening}

Phytochemical screening is a technique for determining the presence of secondary metabolites in extracts with potency as an antiinflammatory agent. The phytochemical analysis revealed that the ethanol extract of Makasar fruit seeds contained phenolic, flavonoid, and terpenoid compounds (Table 1). 
Table 1. Results of phytochemical screening of Makasar fruit seeds ethanol extract

\begin{tabular}{ccc}
\hline Compound & Result & Note \\
\hline Phenolic & + & $\begin{array}{c}\text { A positive result is } \\
\text { indicated by a change in the } \\
\text { color of the green solution. } \\
\text { A positive result is }\end{array}$ \\
Flavonoid & + & $\begin{array}{c}\text { indicated by a change in the } \\
\text { color of the orange solution. } \\
\text { A positive result is } \\
\text { indicated by forming a } \\
\text { purple ring in the solution. }\end{array}$ \\
\hline
\end{tabular}

The presence of phenolics, flavonoids, and terpenoids in the Makassar fruit seed extract is consistent with phytochemical screening from previous findings. It indicated that the ethanol extract of Makassar fruit seeds contained phenolics, flavonoids, triterpenoids, alkaloids, and tannins $[6,12,13]$.

\section{In vitro Anti-inflammatory Activity}

The anti-inflammatory activity of various concentrations of ethanol extract from Makasar fruit seeds was determined in vitro and compared to that of positive control (diclofenac sodium) and negative control (aquadest). The anti-inflammatory activity was determined using the Bovine Serum Albumin (BSA) protein denaturation inhibition method. The principle behind this method is that when BSA is heated, it undergoes denaturation (changes in protein structure and loss of function). It is a marker of protein damage that the body interprets as a foreign object (antigen), thus attempting to combat via an inflammatory mechanism [14,8]. To be considered anti-inflammatory, a substance must inhibit protein denaturation by more than $20 \%$ inhibition percentage.

Table 2 . The results of the anti-inflammatory activity test of positive control (diclofenac sodium) compared to negative control

\begin{tabular}{ccc}
\hline Concentration $(\%)$ & Absorbance & \% Inhibition \\
\hline Negative control & 0.5973 & \\
0.1 & 0.1197 & 79.96 \\
0.25 & 0.0585 & 90.20 \\
0.5 & 0.0514 & 92.39 \\
0.75 & 0.0491 & 91.78 \\
1 & 0.0477 & 92.01 \\
\hline
\end{tabular}

Table 3. The results of the anti-inflammatory activity test of Makasar fruit seed extract compared to negative control

\begin{tabular}{ccc}
\hline Concentration $(\%)$ & Absorbance & \% Inhibition \\
\hline Negative control & 0.5973 & \\
0.1 & 0.4618 & 22.685 \\
0.25 & 0.4444 & 25.598 \\
0.5 & 0.3054 & 48.87 \\
0.75 & 0.2993 & 49.89 \\
1 & 0.1979 & 55.47 \\
2 & 0.2761 & 53.77 \\
3 & 0.4048 & 32.23 \\
4 & 0.4709 & 21.16 \\
5 & 1.4252 & -138.60 \\
\hline
\end{tabular}

Based on the data on the anti-inflammatory activity of the Makasar fruit seed extract in Table 3, the percentage of inhibition increased with the rise of concentration. The optimal inhibition percentage was $55.47 \%$ at a $1 \%$ extract concentration. The inhibition rate decreased as the extract concentration increased above $1 \%$, with the lowest percentage of inhibition occurring at 5\%, namely -138.60 percent. Compared to the control percentage inhibition values in Table 2 , Diclofenac sodium at a concentration of $0.1 \%$ inhibited protein denaturation by $79.96 \%$. The highest percentage of inhibition was $92.01 \%$ for diclofenac sodium positive control at a concentration of $1 \%$. At a concentration of 0.1 percent, Makasar fruit seed extract inhibited protein denaturation but at a lower percentage of inhibition, $22.685 \%$. It demonstrates that the Makasar fruit seed extract has a more negligible inhibitory effect on protein denaturation than the positive control.

Makasar fruit seed extract exhibits antiinflammatory activity due to a greater than $20 \%$ inhibition of protein denaturation. As determined by phytochemical screening, the ethanol extract of Makasar fruit seeds contained secondary metabolites such as phenolics, flavonoids, and terpenoids. These compounds act as antiinflammatory agents in the following mechanism:

a. Phenolic compounds act similarly to NSAIDs (Non-steroidal Anti-Inflammatory Drugs), inhibiting inflammatory mediators. Additionally, phenolic compounds can inhibit the cyclooxygenase enzyme and the NF-kB signaling pathway [17].

b. Flavonoid compounds are reported to act by blocking the enzymes cyclooxygenase and lipoxygenase. Thereby inhibiting the synthesis of inflammatory mediators such as prostaglandins, leukotrienes, histamine, bradykinin, and thromboxane [18]. 
c. Terpenoid compounds have been shown to inhibit cyclooxygenase enzymes, protein denaturation, and cytokine release [19]. The anti-inflammatory activity of the Makasar fruit seed extract is thought to be due to interactions or bonds between secondary metabolite molecules found in the extract and those found in Bovine Serum Albumin (BSA), thereby inhibiting protein denaturation.

Numerous extracts and fruit juices have been shown to have anti-inflammatory activity via the protein denaturation inhibition method. According to Farida et al. (2018), Curcuma nanoparticles had higher anti-inflammatory activity than Curcuma rhizome extract, with an $\mathrm{IC}_{50}$ nanoparticle value of $398.02 \mathrm{ppm}$ [10]. Aditya et al. (2015) demonstrated that mangosteen juice has anti-inflammatory activity with an $\mathrm{IC}_{50}$ of $16.91 \%$ [20]. The relationship between the concentration of Makasar fruit seeds and the percent inhibition of protein denaturation is depicted in Figure 1. The graph indicates that the Makassar fruit seed extract has an $\mathrm{IC}_{50}$ value of $0.76 \%$. Compared to previous studies, the Makassar fruit seed extract exhibited more significant anti-inflammatory activity than mangosteen fruit juice but less than Curcuma nanoparticles.

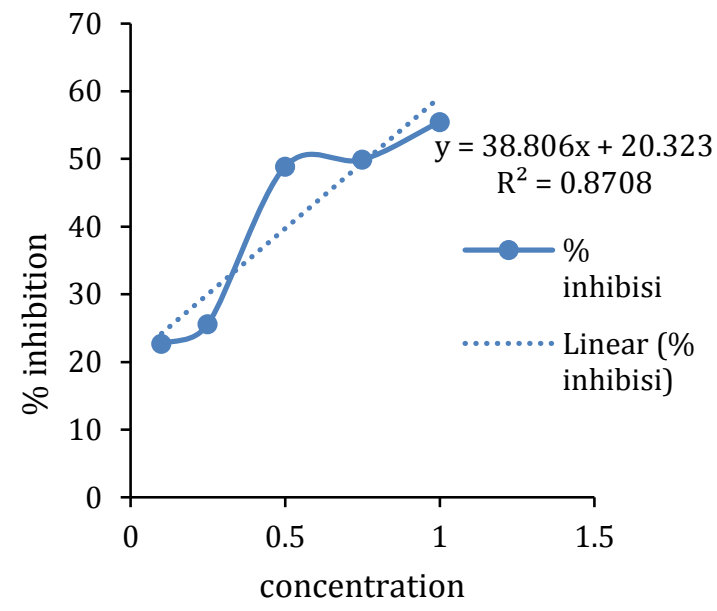

Figure 1. Relationship Graph Between Makasar Fruit Seed Extract Concentration and \% Inhibition

The previous study described that the process of protein denaturation, applied in this study, was caused by heat. When the temperature rises, the kinetic energy of the molecules increases, causing them to vibrate at such a high rate that they are destroyed. Denaturation reduces the liquid's solubility, causing it to settle and cloud the solution. Protein denaturation is a frequent occurrence in the body because of the formation of free radicals, which stimulate the appearance of inflammatory mediators and the emergence of inflammatory mechanisms [21,22].

\section{CONCLUSION}

Makasar [Brucea javanica (L.) Merr.] seed extract was the most effective antiinflammatory agent in vitro at a concentration of $1 \%$ with a percentage of inhibition of $55.47 \%$.

\section{REFERENCES}

[1] Abbas, A.K., \& Litchman, A.(2019).Basic Immunology, Functions and Disorders of the Immune System. Philadelphia: Elsevier.

[2] Katzung,B.G. (2018). Basic \& Clinical Pharmacology, Fourteenth. New York: McGraw Hill Education.

[3] Muliasari,H.,Hamdin,C.D.,\&Ananto,A.D.(2 017). Hypoglycemic effect of Brucea javanica (L) Merr leaves and seed extract in alloxan-induced diabetic rats.ICST.1(1).6267.

[4] Dalimartha, S.(2006). Atlas tumbuhan obat Indonesia, Jilid 2. Jakarta: Trubus Agriwidya.

[5] Chen, M. et al. (2012). Chemical components, pharmacological properties, and nanoparticulate delivery systems of Brucea javanica. Int. J. Nanomedicine.8(1).85-92.

[6] Yang,J., et al.(2013). Anti-inflammatory activity of ethyl acetate fraction of the seeds of Brucea Javanica," J. Ethnopharmacol.147(2).442-446.

[7] Huang,Y.F., et al.(2017). Anti-inflammatory effects of Brucea javanica oil emulsion by suppressing NF- $\mathrm{BB}$ activation on dextran sulfate sodium-induced ulcerative colitis in mice," Journal of Ethnopharmacology.198(1).389-398.

[8] Amini,A.,Hamdin, C.D., Subaidah,W.A., \& Muliasari,H. (2020).Efektivitas Formula Krim Tabir Surya Berbahan Aktif Ekstrak Etanol Biji Wali ( Brucea javanica L . Merr ). 10(1).50-58.

[9] Dearny.(2016).Pengaruh Jenis Pelarut Dan Lama Ekstraksi Terhadap Ekstrak Karotenoid Labu Kuning Dengan Metode Gelombang Ultrasonik. Skripsi.4(1).64-75.

[10] Farida,Y., Rahmat,D., \& Amanda,A.W. (2018). Uji Aktivitas Antiinflamasi Nanopartikel Ekstrak Etanol Rimpang Temulawak (Curcuma xanthorrhiza Roxb.) dengan Metode Penghambatan Denaturasi Protein. J. Ilmu Kefarmasian Indonesia.16(2).225-230.

[11] Ariani,N., Monalisa, \& Febrianti, D.R. (2019). Uji Aktivitas Antibakteri Ekstrak Biji Pepaya (Carica papaya L.) Terhadap Pertumbuhan Escherichia Coli (Test Activity Of Antibacterial Pepaya Seeds (Carica Papaya L.) On Growth Of 
Escherichia Coli). J. Curr. Pharm. Sci.2(2).160166.

[12] Vinatoru,M.(2001). An Overview Of The Ultrasonically Assisted Extraction Of Bioactive Principles From Herbs. Ultrason. Sonochem. 8(3). 303-313.

[13] Quiroz-Reyes, C.N., Aguilar-Méndez,M.A., Ramírez-Ortíz,M.E., \& Ronquillo-De Jesús, E. (2013).Comparative Study Of Ultrasound And Maceration Techniques For The Extraction Of Polyphenols From Cocoa Beans (Theobroma cacao L.). Rev. Mex. Ing. Quim.12(1).11-18.

[14] Risnadewi, W.N., Muliasari, H., Hamdin, C.D., \& Andayani, Y. (2019). Comparative antioxidant Activity Of Brucea javanica (L) Merr Seed Extract Derived From Maceration And Soxhletation Method. AIP Conference Proceedings.2199(1).060003.

[15] Muliasari, H., Hamdin, C.D., Ananto, A.D.\& Ihsan,M. (2019). Chemical Constituents of Buah Makasar [Brucea Javanica (L) Merr] Leaves and Seed Extract. Acta Chim. Asiana. 2(2). 99.

[16] Ingle, P.V., \& Patel, D.M.(2018). Reactive Protein In Various Disease Condition - An Overview .Asian Journal Of Pharmaceutical. 4(1). 9-13.

[17] Ambriz-Perez, D.L., Leyva-Lopez, N. Gutierrez-Grijalva, E.P., \& Heredia, J.B. (2016). Phenolic Compounds: Natural Alternative in Inflammation Treatment. A Review. Cogent Food Agric. 2(1). 2-14.

[18] Ifora, Haryani,D., \& Abdillah,R. (2020). AntiInflammatory Activity And Cyclooxygenase-2 Inhibition Of Ethanol Extract From Malur Leaves ( Brucea javanica (L .) Merr ). J. Pharm. Sci.3(1). 7-13.

[19] Prakash,V. (2017). Terpenoids As Source Of Anti-Inflammatory Compounds. Asian J. Pharm. Clin. Res. 10(3). 68-76.

[20] Aditya, M.R.T., Marisa, D., \& Suhartono,E. (2015). Potensi Antinflamasi Jus Buah Manggis ( Garcinia mangostana) Terhadap Denaturasi Protein In Vitro. Berk. Kedokt.11(2). 149-156.

[21] Borzova, V.A., et al. (2016). Kinetics of Thermal Denaturation And Aggregation Of Bovine Serum Albumin. PLoS One. 11(4).1-29.

[22] Chick,H., \& Martin, C.J. (1911). On Heat Coagulation Protein. J. Physiol. 4(1). 404. 